\title{
Characterizing suitable habitat for the largest remaining population of the threatened Florida scrub-jay Aphelocoma coerulescens
}

\author{
Karl E. Miller*, Colin P. Shea \\ Fish and Wildlife Research Institute, Florida Fish and Wildlife Conservation Commission, 1105 SW Williston Road, \\ Gainesville, FL 32601, USA
}

\begin{abstract}
Birds that breed in early-successional shrubland habitats are declining throughout North America. The Florida scrub-jay Aphelocoma coerulescens depends on Florida scrub, a shrubland plant community endemic to peninsular Florida, USA. The Florida scrub-jay is nonmigratory, federally listed as threatened, globally listed as Vulnerable, and experiencing ongoing population declines. The largest remaining population occurs in Ocala National Forest (Ocala $\mathrm{NF}$ ), where the effects of intensive management of scrub for forest product extraction are unknown. During 2011-2014, we conducted the first quantitative evaluation of Florida scrub-jay density and productivity at Ocala NF in relation to the age, size, and connectivity of early-successional habitat patches. Regenerating clearcut stands 3-10 yr post-harvest provided suitable habitat conditions for Florida scrub-jays, with the maximum number of family groups and juveniles occurring in stands 6.5 and $7.4 \mathrm{yr}$ post-harvest, respectively. Our findings indicate that previous definitions of suitable habitat for the species in Ocala NF (e.g. 0-20, 3-15, 3-12 yr post-harvest) are overly broad. We suggest that managers define suitable habitat conservatively given that few stands $>10$ yr post-harvest were occupied by scrub-jays, and annual productivity in those stands was relatively low. Our findings that scrub-jays readily occupied small scrub patches and did not avoid forested edges should be interpreted with caution, and more demographic study is needed to understand survival and dispersal among patches. Managers can maximize Florida scrub-jay populations in Ocala NF by increasing the availability of habitat that is within 3-10 yr post-harvest.
\end{abstract}

KEY WORDS: Shrubland birds · Florida scrub-jay $\cdot$ Suitable habitat $\cdot$ Density $\cdot$ Productivity · Florida scrub

\section{INTRODUCTION}

Birds that breed in early-successional shrubland habitats are declining more rapidly than most bird species in North America (Hunter et al. 2001, Dettmers 2003), and quantifying and managing suitable habitat for these species is critically important. Shrubland habitats rely on disturbance, both natural and anthropogenic, and alteration of spatial and temporal patterns of disturbance presents ongoing man-

${ }^{*}$ Corresponding author: karl.miller@myfwc.com agement challenges and opportunities (Askins 2001, 2002, Thompson \& DeGraaf 2001, DeGraaf \& Yamasaki 2003, Litvaitis 2003, Shake et al. 2012). Shrubland habitats are now among the rarest habitats in the northeastern USA (DeGraaf \& Yamasaki 2003). In Florida, early-successional upland plant communities (shrublands, dry prairie, and scrub) have been converted to agriculture at a more rapid pace than has any other plant community in the state (Kautz et al. 2007).

(C) The authors 2021. Open Access under Creative Commons by Attribution Licence. Use, distribution and reproduction are unrestricted. Authors and original publication must be credited. 
The Florida scrub-jay Aphelocoma coerulescens is a habitat-restricted endemic species that continues to decline because of habitat loss, habitat fragmentation, and management challenges related to firemaintained early-successional habitat. The Florida scrub-jay depends on Florida scrub, a narrowly distributed shrubland plant community occurring on nutrient-poor sandy ridges in peninsular Florida, USA (Myers 1990, Florida Natural Areas Inventory 2010). Florida scrub is characterized by mostly treeless, open expanses of low shrubs dominated by evergreen, or nearly evergreen, oak species Quercus spp. Infrequent but high-intensity wildfire and, more recently, prescribed burning and mechanical treatments (Williges et al. 2006, Weekley et al. 2011) maintain Florida scrub in an early-successional state.

The Florida scrub-jay is listed as threatened by the US Fish and Wildlife Service (USFWS 1987) and Vulnerable by the International Union for the Conservation of Nature (IUCN; Handbook of Birds of the World and BirdLife International 2018) but could be reclassified by the IUCN as Endangered if human development continues to degrade and eliminate its habitat (BirdLife International 2000). The species is nonmigratory and lives in extended cooperative family groups that are territorial and largely sedentary (i.e. most males disperse no farther than 1 to 2 territory widths away from their natal territory; Woolfenden \& Fitzpatrick 1984, 1996, Fitzpatrick et al. 1999). Habitat loss and habitat degradation due to fire suppression throughout the species' range have caused widespread population declines, estimated at $90 \%$ since the late 1800 s (Stith et al. 1996, Woolfenden \& Fitzpatrick 1996). Recent surveys indicate Florida scrub-jay populations continue to decline on many public conservation lands, with lack of earlysuccessional scrub believed to be the primary cause (USFWS 2007, Boughton \& Bowman 2011).

The nest success and productivity of Florida scrubjay decline in unburned scrub dominated by tall ( $>2 \mathrm{~m}$ ) vegetation (Woolfenden \& Fitzpatrick 1984, Breininger et al. 1998, Breininger \& Oddy 2004). Habitat management guidelines developed for Florida scrubjays on the Atlantic coast promote scrub vegetation of medium height (1.2 to $1.7 \mathrm{~m}$ tall) with patchy openings of bare sand and few, or no, trees (Breininger et al. 1998, 2014, Breininger \& Carter 2003, Florida Fish and Wildlife Conservation Commission [FWC] 2019). To guard against avian predators, the Florida scrubjay uses a cooperative sentinel system (McGowan \& Woolfenden 1989) that functions best when vegetation is low so that views are unobstructed by trees. Florida scrub-jay occupancy and demography are negatively affected by proximity to forest edge, particularly hardwood forest (Breininger et al. 1995, Burgman et al. 2001). However, less is known about the impact of adjacent sand pine Pinus clausa forest on scrub-jays. Sand pines are a precocious colonizer of scrub, producing cones as early as $5 \mathrm{yr}$ of age (Brendemuehl 1990), but frequent fire can reduce or eliminate sand pines from scrub (Myers 1990, Freeman \& Kobziar 2011).

The Ocala National Forest (Ocala NF) supports the largest remaining Florida scrub-jay population (>800 family groups; Stith et al. 1996, USFWS 2007) and is one of only 3 metapopulations with a high probability of long-term persistence (Stith 1999, USFWS 2007). Ocala NF encompasses approximately 91000 ha of scrub habitat managed for multiple objectives including forest products, wildlife habitat, and recreation. Whereas land managers of other Florida scrub-jay populations actively suppress sand pine with prescribed burning, at Ocala NF sand pine is intentionally regenerated for pulpwood and plantations are not burned (USFS [US Forest Service] 1999, 2009). The Ocala NF landscape is thus unique in that early successional habitat for Florida scrub-jays occurs in hundreds of small (mostly 10 to 60 ha) clearcut stands of regenerating scrub embedded within an extensive matrix of sand pine forest unsuitable for scrub-jays. The long-term effects of Ocala NF management of sand pine scrub on individual wildlife species are largely unknown.

Successional trajectories for shrubland bird species vary among species and from site to site (Greenberg et al. 2011, Watson et al. 2012, Perry \& Thill 2013). Disturbance intervals necessary to achieve and maintain suitable habitat conditions for Florida scrub-jays vary depending on local site conditions and previous management histories (FWC 2019). For example, fire intervals of 8 to $15 \mathrm{yr}$ have been recommended for scrub on xeric ridges in central Florida (Woolfenden \& Fitzpatrick 1996), but shorter intervals are recommended for scrub elsewhere in the state, especially in more mesic sites (Florida Natural Areas Inventory 2010). Managers recommend burning scrub on the Atlantic coast at 2 to 5 yr intervals to maintain openings (M. Legare pers. comm.).

Successional relationships for the Florida scrub-jay have not been described quantitatively in Ocala NF, even though it is the largest and most important population for recovery efforts (USFWS 2007). Assumptions about what constitutes suitable habitat in this unique system have ranged from 3-15 yr postharvest (USFS 1999) to 3-12 yr post-harvest (USFS 2009) and more recently 'a mosaic of stands $\leq 20 \mathrm{yr}$ of 
age' (Franzreb \& Zarnoch 2011, p. 1040). Given the Florida scrub-jay's limited dispersal ability (Woolfenden \& Fitzpatrick 1984, Fitzpatrick et al. 1999), its sensitivity to habitat fragmentation (Coulon et al. 2010, 2012), and its tendency to avoid canopied forest elsewhere (Breininger et al. 1995, Burgman et al. 2001), the status and trend of this important population remain uncertain and of urgent conservation concern. Therefore, we conducted the first quantitative evaluation of Florida scrub-jay populations in Ocala NF in relation to forest stand age, stand size, and connectivity among stands (i.e. nearest neighbor distances). We predicted that the number of Florida scrub-jay family groups and their annual productivity would be positively related to patch size and connectivity and negatively related to stand age. Our ultimate objective was to provide a quantitative basis for refining the definition of suitable Florida scrubjay habitat in Ocala NF to assist managers in tracking population recovery goals.

\section{MATERIALS AND METHODS}

\subsection{Study area}

Ocala NF encompasses approximately 155000 ha in Lake, Marion, and Putnam counties in central Florida, USA (Fig. 1), and is bordered on the west by the Ocklawaha River and on the east by the St. Johns River. Approximately two-thirds of Ocala NF is made up of the largest contiguous patch of scrub in Florida, which is characterized by nutrient-poor sandy soils (Astatula-Paola association) on gently rolling dunelike ridges formed during the Pleistocene (Soil Conservation Service 1968, Myers 1990). All types of Florida scrub are pyrogenic plant communities historically maintained in an early-successional state by infrequent but high-intensity wildfires. Florida scrub in Ocala NF is characterized by 3 species of oaks: myrtle Quercus myrtifolia, Chapman's Q. chapmanii, and sand live oak Q. geminata (Myers 1990). Without disturbance, most scrub at Ocala NF eventually succeeds to sand pine forest, which has been managed for commercial harvesting since the 1940s (Hinchee \& Garcia 2017).

\subsection{Sampling design}

Most potential scrub habitat at Ocala NF $(93 \%$ at the start of the study period; J. Drake pers. comm.) is managed with silvicultural practices that promote the

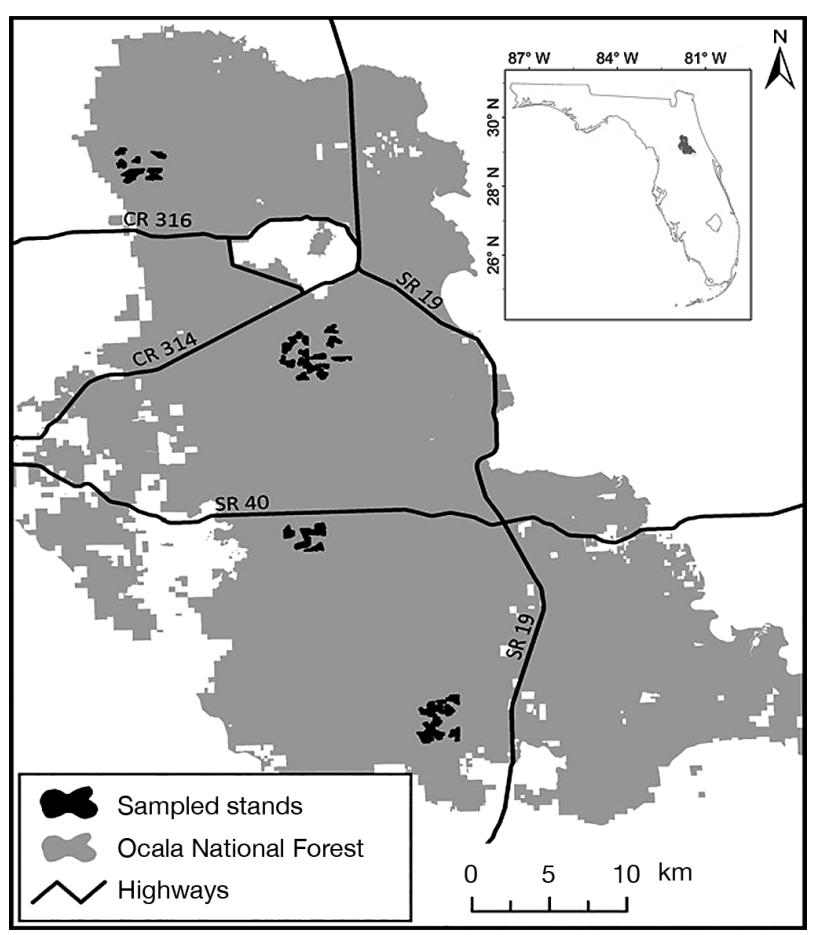

Fig. 1. Florida scrub-jays were monitored at early successional forest stands within 4 study sites in Ocala National Forest, Florida, USA, 2011 to 2014. SR: State Road; CR: County Road

growth and harvest of sand pines for pulpwood, including clearcutting, roller chopping, and reseeding and/or natural regeneration of sand pine (USFS 1999, 2009). Because our goal was to assess the effects of management of sand pine scrub for pulpwood, we excluded any scrub habitat not managed for pulpwood, including areas within a designated wilderness area and a military installation, from our sampling. We divided the Ocala NF into 4 zones to account for a slightly increasing north-to-south gradient in the amount of scrub-jay habitat in early successional condition (J. Drake pers. comm.) and used a stratified random sampling approach (Thompson 2012) to select one $7.77 \mathrm{~km}^{2}$ (3 square miles) rectangular study site within each of the 4 zones for inclusion in a longterm monitoring program. Within each of the 4 selected study sites, we monitored Florida scrub-jays at all clearcut stands $<15$ yr since harvest $(n=27$ in 2011-2013, $\mathrm{n}=26$ in 2014; Fig. 1). Those stands included a range of sizes $(23.3 \pm 10.7$ [mean $\pm \mathrm{SD}$ ] ha, range: 6.8-61.9 ha) and ages (as of 2011: $5.7 \pm 3.5 \mathrm{yr}$, range: 0-13 yr). During 2012 to 2014, we monitored additional stands just outside the margins of the $7.77 \mathrm{~km}^{2}$ study sites to increase the number of stands and family groups included in our analysis of habitat relationships. Total stands surveyed were 45 (2012), 34 (2013), and 31 (2014). 


\subsection{Data collection}

We monitored Florida scrub-jay family groups during the breeding seasons (mid-March through early July) of 2011 to 2014 using color banding, territory mapping, and a post-reproductive survey to determine population size and annual productivity (Woolfenden \& Fitzpatrick 1984, Fitzpatrick et al. 1991). These methods are well suited for scrub-jay demographic monitoring because they delineate the number of family groups per unit area, which is the metric of management interest for a cooperatively breeding species such as the Florida scrub-jay (Fitzpatrick et al. 1991, USFWS 2007, Boughton \& Bowman 2011). Occupancy modeling and distance sampling are unreliable for this species because scrub-jay behavior violates important assumptions of those methodologies (e.g. scrub-jays often approach observers and thus are usually not detected at their initial location; see Buckland et al. 1993), nor do those approaches readily delineate the number and size of extended family groups.

We captured and banded scrub-jays throughout the year, but most frequently during the nonbreeding season, with field methods used successfully with this species for nearly 4 decades (e.g. Woolfenden \& Fitzpatrick 1984, Breininger et al. 1995, 2014, Fitzpatrick et al. 1999, Breininger \& Carter 2003). We trap-tamed and captured scrubjays with walk-in Potter traps and drop traps baited with peanuts and mealworms and banded them with a numbered federal aluminum band and a unique combination of 3 plastic color bands. Trap taming was a short-lived process lasting only days or weeks and involved providing a small amount of food targeted to unbanded individuals. Our goal was to color band at least 1 adult member of each family group in stands containing $>1$ family group to better understand membership of family groups and to facilitate mapping their territories during surveys. By late fall $2013,>50 \%$ of the population was color banded. Trapping and banding protocols followed established guidelines for the use of wild birds in research (Fair et al. 2010).

Field staff conducted detailed monitoring and territory mapping (e.g. Woolfenden \& Fitzpatrick 1984, Breininger et al. 1995, 2014, Fitzpatrick et al. 1999, Breininger \& Carter 2003). during the breeding season peak (April to June) in forest stands $\leq 12$ yr post-harvest within each of the 4 sites. Observations were recorded in the field on aerial photos ranging from 1:2400 to 1:13000. Sex and breeding status of scrub-jays were determined through vocalizations (the female-specific 'hiccup' call) and behavior (only females incubate eggs; Woolfenden \& Fitzpatrick 1996), and special attention was given to noting locations of territorial encounters between neighboring family groups (Fitzpatrick et al. 1991, Breininger et al. 2014) to delineate approximate territory boundaries (Bibby et al. 1992). Although intensive nest monitoring was outside the scope of our study, some nests were located opportunistically, which helped define territory locations and group membership. We discovered early in the project that stands 12 to $15 \mathrm{yr}$ since harvest were rarely occupied, so many of those stands were monitored only during a postreproductive survey (see following paragraph).

We also conducted an intensive post-reproductive productivity survey on all stands during 20 June to 10 July each year, when juveniles can be easily distinguished from adults by plumage. Timing of this survey provided an annual benchmark for analysis of density and annual productivity (Woolfenden \& Fitzpatrick 1984, Fitzpatrick et al. 1991). We established a grid of permanent survey points spaced 125 to $150 \mathrm{~m}$ apart in each stand. Monitoring methods were based on Fitzpatrick et al. (1991) and current protocols for the Jay Watch program (Audubon Florida 2015). Teams of paired observers played recordings of Florida scrub-jay territorial 'weep' and 'hiccup' calls (Woolfenden \& Fitzpatrick 1996) for three $1 \mathrm{~min}$ periods at each survey point to elicit responses from resident scrub-jays (Audubon Florida 2015). We used a variety of vocalizations, most of which we recorded locally in Ocala NF, to enhance response. The Florida scrub-jay is typically a conspicuous and vocal species, and playback surveys produce detection rates $>0.90$ (K. Sieving \& T. Castellon unpubl. data). We visited each survey point $\geq 3$ times on separate mornings, typically not on consecutive days. Territorial interactions were used to delineate number of family groups and determine number of adults and number of juveniles within each family group. Use of paired observers maximized the likelihood of maintaining visual contact with observed family groups and helped avoid double counting. Training for participants was provided each year prior to monitoring to ensure accuracy of data collection.

\subsection{Data analysis}

We analyzed data from 2011 to 2014 using generalized linear mixed models to assess the influence of stand age, stand size, and distance to nearest 
neighboring stand on 3 separate scrub-jay response variables, all of which were integer counts: the number of family groups, the number of adults, and the number of juveniles. Preliminary analyses indicated that although a Poisson regression was suitable for the family group response variable, there was evidence of overdispersion in the adult and juvenile Poisson regression models; hence, a negative binomial model was used for adults and juveniles instead. In each model, we included a random effect for year and random effect for study site (Gelman \& Hill 2007). We also included an additional random effect for study site $x$ year for adults and juveniles to account for the nested structure of the data (model convergence problems prevented inclusion of a study site $x$ year random effect in the family group Poisson regression model). Field knowledge suggested apparent nonlinear relationships with stand age, so we included a quadratic term for stand age in each model. Predicted values were calculated across the observed range of each predictor variable at the mean observed value of the other response variables. Distance to nearest potentially suitable neighboring stand was determined with ArcGIS (Environmental Systems Research Institute) by calculating straight-line distances (m) from the perimeter of each stand to the perimeter of the nearest stand $\leq 12$ yr post-harvest. Nearest neighbor distances ranged from 0 to $504 \mathrm{~m}$ $(128.3 \pm 170.13 \mathrm{~m}$ [mean $\pm \mathrm{SD}])$. To facilitate model-fitting, we standardized all continuous predictor variables with mean 0 and standard deviation of 1. For all models we considered parameter estimates important if their $95 \%$ confidence intervals did not overlap zero. Lastly, we assessed goodness-of-fit for each model using a simulation-based assessment of scaled residuals as implemented in the $\mathrm{R}$ package DHARMa (Hartig 2020). All Poisson and negative binomial regression models (Gelman \& Hill 2007) were fitted in $R$ v4.0.3 (R Core Team 2020) using the glmmTMB package (Brooks et al. 2017).

\section{RESULTS}

There was a positive curvilinear (quadratic) relationship between stand age and each of the response variables: family groups, adults, and juveniles (Table 1, Fig. 2). The greatest number of Florida scrub-jays occurred at stands of intermediate age. The Poisson model indicated that the maximum number of family groups occurred at stands of $6.5 \mathrm{yr}$, and the negative binomial models found that the maximum number of adults and juveniles occurred at stands of 6.8 and $7.4 \mathrm{yr}$, respectively. We rarely observed scrub-jays occurring in stands $<3$ or $>10 \mathrm{yr}$ post-harvest. The only 12 yr old stand that was occu-

Table 1. Parameter estimates, standard errors (SE), and lower and upper $95 \%$ confidence limits from the negative binomial (adults and juveniles) and Poisson (family groups) regression models relating Stand age (yr), Stand area (ha), and Distance to nearest stand $(\mathrm{m})$ to the number of individuals (adults and juveniles) or family groups in a stand. Random effects associated with Year and Site $\times$ Year are expressed as standard deviations. Parameter estimates associated with Stand age, Stand area, and Distance are interpreted as change in response for a $1 \mathrm{SD}$ unit change in the predictor (Stand age: mean $=7.2, \mathrm{SD}=3.5$;

Stand area: mean $=24.1, \mathrm{SD}=11.6$; Distance: mean $=128.3, \mathrm{SD}=170.1$ )

\begin{tabular}{|c|c|c|c|c|}
\hline Parameter & Estimate & $\mathrm{SE}$ & Lower & Upper \\
\hline \multicolumn{5}{|l|}{ Family groups } \\
\hline \multicolumn{5}{|l|}{ Fixed effects } \\
\hline Intercept & 1.111 & 0.079 & 0.957 & 1.265 \\
\hline Stand age & -0.206 & 0.086 & -0.374 & -0.037 \\
\hline Stand age $^{2}$ & -0.397 & 0.076 & -0.545 & -0.249 \\
\hline Stand area & 0.339 & 0.052 & 0.237 & 0.442 \\
\hline Distance & 0.086 & 0.064 & -0.039 & 0.212 \\
\hline \multicolumn{5}{|l|}{ Random effects } \\
\hline Intercept (Year) & 0.031 & & & \\
\hline \multicolumn{5}{|l|}{ Adults } \\
\hline \multicolumn{5}{|l|}{ Fixed effects } \\
\hline Intercept & 1.961 & 0.085 & 1.794 & 2.128 \\
\hline Stand age & -0.177 & 0.066 & -0.307 & -0.047 \\
\hline Stand $_{\text {age }}^{2}$ & -0.421 & 0.059 & -0.537 & -0.305 \\
\hline Stand area & 0.319 & 0.045 & 0.231 & 0.407 \\
\hline Distance & 0.104 & 0.053 & -0.001 & 0.209 \\
\hline \multicolumn{5}{|l|}{ Random effects } \\
\hline Intercept (Year) & 0.102 & & & \\
\hline Intercept (Site $\times$ Year) & 0.104 & & & \\
\hline Theta & 14.706 & & & \\
\hline \multicolumn{5}{|l|}{ Juveniles } \\
\hline \multicolumn{5}{|l|}{ Fixed effects } \\
\hline Intercept & 0.744 & 0.226 & 0.3 & 1.188 \\
\hline Stand age & 0.024 & 0.147 & -0.264 & 0.312 \\
\hline Stand age ${ }^{2}$ & -0.559 & 0.141 & -0.835 & -0.283 \\
\hline Stand area & 0.371 & 0.108 & 0.16 & 0.582 \\
\hline Distance & -0.016 & 0.143 & -0.297 & 0.265 \\
\hline \multicolumn{5}{|l|}{ Random effects } \\
\hline Intercept (Year) & 0.272 & & & \\
\hline Intercept (Site $\times$ Year) & 0.330 & & & \\
\hline Theta & 1.416 & & & \\
\hline
\end{tabular}



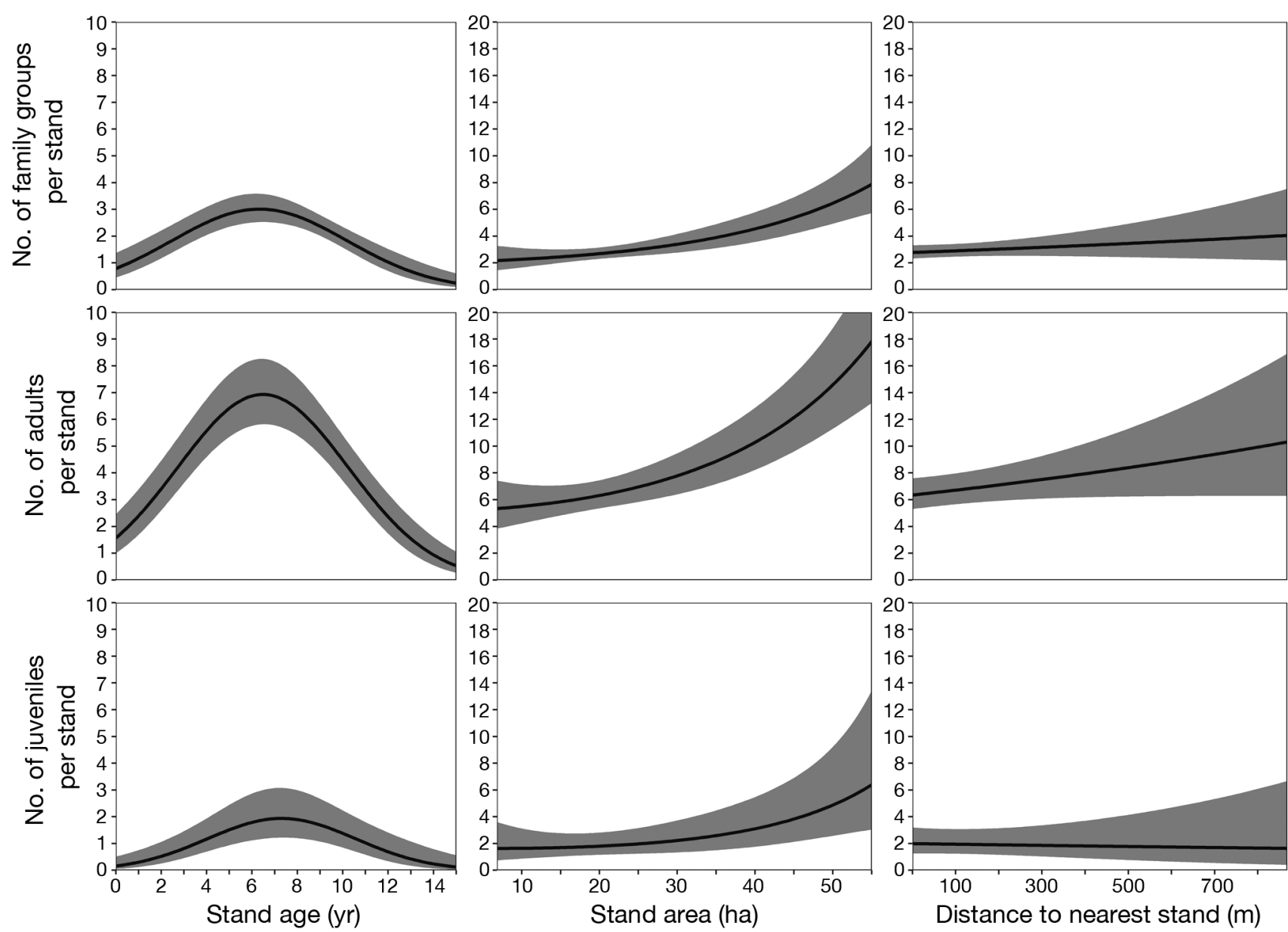

Fig. 2. Effect of stand age, stand area, and distance to nearest stand on the mean (solid black line) number of Florida scrubjay family groups, adults, and juveniles per stand in Ocala National Forest, 2011 to 2014. Predictions were calculated across the observed range of each predictor variable at the mean observed value of the other response variables (Stand age: mean $=$ 7.2; Stand area: mean $=24.1$; Distance to nearest stand: mean $=128.3$ ). Shaded regions represent $95 \%$ confidence intervals

pied by scrub-jays was an atypical patch that happened to be bordered on all sides by wide (20 to $35 \mathrm{~m}$ ) sandy roads and road shoulders that created openings attractive for scrub-jays.

There was also a positive linear relationship between stand area and each of the response variables: family groups, adults, and juveniles (Table 1, Fig. 2). Although Florida scrub-jay numbers increased as patch size increased, we also found that small stands (including the smallest stand [6.8 ha] that we surveyed) supported scrub-jay families and produced juveniles (Fig. 2). Indeed, parameter estimates indicated that the mean number of family groups, adults, and juveniles increased with stand area at approximately the same rate.

The influence of distance to nearest suitable stand on all response variables was inconclusive, as the $95 \%$ confidence intervals of parameter estimates overlapped zero (Table 1). The slopes of the predicted relationships were relatively flat, indicating a lack of a relationship (Fig. 2). Lastly, goodness-of-fit diagnostics indicated that both the Poisson regression model (family groups) and negative binomial regression models (adults and juveniles) provided an adequate fit to the data.

\section{DISCUSSION}

Our project provides the first quantitative basis for evaluating previous characterizations of suitable Florida scrub-jay habitat in Ocala NF as 3 to $15 \mathrm{yr}$ post-harvest (Greenberg et al. 1995, USFS 1999) or 3 to 12 yr post-harvest (USFS 2009). Franzreb \& Zarnoch (2011, p. 1040) recommended '...maintaining a mosaic of stands $\leq 20 \mathrm{yr}$ of age' to increase the Florida 
scrub-jay population at Ocala NF. Our data suggest that those definitions and recommendations may be overly broad. Scrub-jay density and productivity were greatest in 6 to $8 \mathrm{yr}$ old stands, with a precipitous drop after $10 \mathrm{yr}$ post-harvest. Scrub-jays were rarely found in older stands except along edges where they used adjacent sandy openings or roadways as habitat. Similarly, a nest-monitoring study at Ocala NF found that most (78\%) Florida scrub-jay nests were located in 6 to $10 \mathrm{yr}$ old stands, with relatively few nests in 11 to 15 yr old stands (Franzreb \& Zarnoch 2011). In our study, colonization of some stands $<3$ yr after disturbance was more comparable to the rapid occupancy of Atlantic coastal scrub postfire (D. R. Breininger pers. comm.) than the slower occupancy of southern Florida xeric scrub post-fire (Woolfenden \& Fitzpatrick 1996).

The smallest patches in our study area were consistently occupied by at least 1 scrub-jay family group. Contrary to our expectations, we found no evidence that Florida scrub-jays had reduced productivity in small patches with more edge, as evidenced by the similarity of estimated slopes for family groups and juveniles in relation to stand area (Table 1, Fig. 2). In contrast, scrub-jays on the Atlantic coast avoided forested edges (Breininger et al. 1995) or showed declining nest survival in proximity to forested edges (Carter et al. 2011). Potential disadvantages of a smaller patch size might be mediated by whether scrub-jays are able to use the margins of small scrub stands effectively. Previous work in Ocala NF concluded that Florida scrub-jays may enter pine forest edges depending on the characteristics of the surrounding habitat matrix (Abel 2014).

However, conclusions about forested edges in our study area may not be generalizable to other localities that support populations of accipiters, which are the primary predators of adult scrub-jays elsewhere (Woolfenden \& Fitzpatrick 1996, USFWS 2007). We suspect that scrub-jays have a relatively low likelihood of encountering aerial predators at Ocala NF. The Cooper's hawk Accipiter cooperii was not confirmed breeding in Ocala NF during a Breeding Bird Atlas survey (FWC 2003) and was rarely observed in our study sites during 2011 to 2014 (A. Fasoli \& K. E. Miller pers. obs.).

We found no evidence that more isolated stands were less likely to be used by scrub-jays or that they had fewer scrub-jays or lower productivity. However, most stands that we monitored happened to be contiguous with another stand or located a relatively short distance from another potentially suitable stand (i.e. $>90 \%$ of the stands we studied were $<300 \mathrm{~m}$ from another suitable stand). Our stratified random sampling approach captured a range of conditions typical of harvested stands at Ocala NF, rather than identifying and studying the most isolated stands in the forest. Further study across a wider landscape gradient potentially might reveal a threshold beyond which scrub-jays are inhibited from colonizing and occupying clearcut stands at Ocala NF. Consequences of habitat fragmentation on wildlife are determined not only by the shape, size, and location of patches but also characteristics of the habitat matrix between those patches (Ewers \& Didham 2006), and future analysis of scrub-jay movements could consider a broader array of landscape variables.

Our findings that scrub-jays occupied small scrub patches and used the edges of scrub patches should be interpreted with caution, given that most shrubland bird species that have been studied have higher abundances in the centers of early-successional habitat patches than along edges (Schlossberg \& King 2008). Even though we confirmed that some Florida scrub-jays at Ocala NF are able to occupy the margins of stands $>10$ yr post-harvest, it is possible that those areas constituted population sinks (i.e. annual mortality exceeded annual reproduction) given the overgrown vegetation in those stands (oaks 2.0 to $3.5 \mathrm{~m}$ in height; K. E. Miller unpubl. data) and the low numbers of juveniles we observed there (Fig. 2). Elsewhere, Florida scrub-jay demographic performance declined when oak scrub height was $>1.7 \mathrm{~m}$ (Burgman et al. 2001, Breininger \& Carter 2003, Breininger et al. 2006). Additional research about how family group size influences productivity (e.g. Mumme 1992, Mumme et al. 2015) across a range of habitat conditions and management scenarios in Ocala NF would be useful for managers.

In summary, our study provides the first rigorous assessment of Florida scrub-jay habitat relationships in this unique and important population. More demographic study is needed to understand survivorship and dispersal within and among patches, but regenerating scrub stands appear to provide suitable habitat conditions for Florida scrub-jays for only 3 to $10 \mathrm{yr}$ post-harvest, with optimal conditions attained during a relatively brief period (6 to 8 yr post-harvest). Although a broader range of successional conditions may be used by scrub-jays, we suggest that managers define suitable habitat conservatively given that few stands $>10$ yr post-harvest were occupied and productivity in those stands was relatively low. Managers can maximize Florida scrub-jay populations in Ocala NF by increasing the availability of habitat that is within 3 to 10 yr post-harvest. Expand- 
ing the amount of early successional scrub habitat at Ocala NF can be accomplished by increasing the annual acreage of sand pine harvested for pulpwood, by setting aside zones managed with fire as scrubjay management areas (Weekley et al. 2011, Hinchee \& Garcia 2017), or by some combination of both.

Acknowledgements. We thank the Ocala NF scrub-jay working group, especially C. Faulhaber (FWC), J. Garcia (USFS), and M. Jennings (USFWS), for their support for the project concept. Dozens of field assistants and volunteers assisted with banding and monitoring Florida scrub-jays, including B. Carpenter, K. Cattrano, G. Conn, C. Enloe, A. Fasoli, C. Faulhaber, J. Garcia, M. Mietzelfeld, A. Sirman, and M. Wilcox. R. Butryn prepared survey maps and derived spatial statistics, and E. Leone assisted with data analyses. Funding for the project was provided primarily by FWC's Nongame Wildlife Trust Fund with additional support from USFWS Section 6 federal funds. Earlier versions of the manuscript were improved by the comments of A. Cox, C. Faulhaber, B. Hyde, and 2 anonymous reviewers.

\section{LITERATURE CITED}

Abel AM (2014) Florida scrub-jay movement through unsuitable habitat and its relationship to occupancy in Ocala National Forest. Masters thesis, University of Florida, Gainesville, FL

Askins RA (2001) Sustaining biological diversity in early successional communities: the challenge of managing unpopular habitats. Wildl Soc Bull 29:407-412

Askins RA (2002) Restoring North America's birds. Yale University Press, New Haven, CT

Audubon Florida (2015) Jay Watch volunteer training manual. Audubon Florida, Tallahassee, FL

Bibby CJ, Burgess ND, Hill DA (1992) Bird census techniques. Academic Press, San Diego, CA

BirdLife International (2000) Threatened birds of the world. Lynx Edicions and BirdLife International, Barcelona and Cambridge

Boughton R, Bowman R (2011) Statewide assessment of Florida scrub-jays on managed areas: a comparison of current populations to the results of the 1992-93 survey. Final report, US Fish and Wildlife Service, Jacksonville, FL

Breininger DR, Carter G (2003) Territory quality transitions and source-sink dynamics in a Florida scrub-jay population. Ecol Appl 13:516-529

Breininger DR, Oddy DM (2004) Do habitat potential, population density, and fires influence scrub-jay source-sink dynamics? Ecol Appl 14:1079-1089

Breininger DR, Larson VL, Duncan BW, Smith RB, Oddy DM, Goodchild MF (1995) Landscape patterns of Florida scrub-jay habitat use and demographic success. Conserv Biol 9:1442-1453

Breininger DR, Larson VL, Duncan BW, Smith RB (1998) Linking habitat suitability to demographic success in Florida scrub-jays. Wildl Soc Bull 26:118-128

Breininger DR, Toland B, Oddy DM, Legare ML (2006) Landcover characterizations and Florida scrub-jay (Aphelocoma coerulescens) population dynamics. Biol Conserv 128:169-181

Breininger DR, Stolen ED, Carter GM, Oddy DM, Legare SA
(2014) Quantifying how territory quality and sociobiology affect recruitment to inform fire management. Anim Conserv 17:72-79

Brendemuehl RH (1990) Pinus clausa (Chapm. ex. Engelm.) Vasey ex. sand pine. In: Burns RM, Honkala BH (eds) Silvics of North America. Vol 1, Conifers. US Forest Service, Washington, DC, p 294-301

Brooks ME, Kristensen K, van Benthem KJ, Magnusson A and others (2017) glmmTMB balances speed and flexibility among packages for zero-inflated generalized linear mixed modeling. R J 9:378-400

Buckland ST, Anderson DR, Burnham KP, Laake JL (1993) Distance sampling: estimating abundance of biological populations. Chapman and Hall, London

*Burgman MA, Breininger DR, Duncan BW, Ferson S (2001) Setting reliability bounds on habitat suitability indices. Ecol Appl 11:70-78

Carter G, Breininger DR, Stolen ED, Oddy DM (2011) Determinants of nest survival in a managed Florida scrub-jay population. Condor 113:629-636

Coulon A, Fitzpatrick JW, Bowman R, Lovette IJ (2010) Effects of habitat fragmentation on effective dispersal of Florida scrub-jays. Conserv Biol 24:1080-1088

Coulon A, Fitzpatrick JW, Bowman R, Lovette IJ (2012) Mind the gap: genetic distance increases with habitat gap size in Florida scrub-jays. Biol Lett 8:582-585

* DeGraaf RM, Yamasaki M (2003) Options for managing earlysuccessional forest and shrubland bird habitats in the northeastern United States. For Ecol Manage 185:179-191

* Dettmers R (2003) Status and conservation of shrubland birds in the northeastern US. For Ecol Manage 185:81-93

Ewers RM, Didham RK (2006) Confounding factors in detection of species responses to habitat fragmentation. Biol Rev Camb Philos Soc 81:117-142

Fair J, Paul E, Jones J (eds) (2010) Guidelines to the use of wild birds in research. Ornithological Council, Washington, DC

Fitzpatrick JW, Kopeny MT, Woolfenden GE (1991) Ecology and development-related habitat requirements of the Florida scrub Jay (Aphelocoma coerulescens coerulescens). Nongame Wildlife Program, Technical Report No. 8. Florida Game and Fresh Water Fish Commission, Tallahassee, FL

Fitzpatrick JW, Woolfenden GE, Bowman R (1999) Dispersal distance and its demographic consequences in the Florida scrub-jay. Symposium S41.2. In: Adams NJ, Slotow RH (eds) Proc 22nd Int Ornithol Congr, Durban, p 2465-2479

Florida Natural Areas Inventory (2010) Revised guide to the natural communities of Florida. Florida Natural Areas Inventory, Tallahassee, FL

Franzreb KE, Zarnoch SJ (2011) Factors affecting Florida scrub-jay nest survival in Ocala National Forest, Florida. J Wildl Manag 75:1040-1050

Freeman JE, Kobziar LN (2011) Tracking postfire successional trajectories in a plant community adapted to highseverity fire. Ecol Appl 21:61-74

FWC (Florida Fish and Wildlife Conservation Commission) (2003) Florida's breeding bird atlas: a collaborative study of Florida's birdlife. www.myfwc.com/bba/ (accessed 1 September 2018)

FWC (2019) Scrub management guidelines. Florida Fish and Wildlife Conservation Commission, Tallahassee, FL

Gelman A, Hill J (2007) Data analysis using regression and multilevel/hierarchical models. Cambridge University Press, New York, NY 
Greenberg CH, Harris LD, Neary DG (1995) A comparison of bird communities in burned and salvage-logged, clearcut, and forested Florida sand pine scrub. Wilson Bull $107: 40-54$

Greenberg CH, Collins BS, Thompson FR III (eds) (2011) Sustaining young forest communities: ecology and management of early successional habitats in the central hardwood region, USA. Managing Forest Ecosystems, Vol 21. Springer, New York, NY

Handbook of Birds of the World and BirdLife International (2018) Handbook of the Birds of the World and BirdLife International digital checklist of the birds of the world. Version 3. http://datazone.birdlife.org/userfiles/file/ Species/Taxonomy/HBW-BirdLife_Checklist_v3_Nov18. zip (accessed 23 September 2019)

Hartig F (2020) DHARMa: residual diagnostics for hierarchical (multi-level/mixed) regression models. R package version 0.3.3.0. https://CRAN.R-project.org/package= DHARMa

Hinchee JK, Garcia JO (2017) Sand pine and Florida scrubjays - an example of integrated adaptive management in a rare ecosystem. J For 115:230-237

Hunter WC, Buehler DA, Canterbury RA, Confer JL, Hamel PB (2001) Conservation of disturbance-dependent birds in eastern North America. Wildl Soc Bull 29:440-455

Kautz R, Stys B, Kawula R (2007) Florida vegetation 2003 and land use change between 1985-89 and 2003. Fla Sci $70: 12-23$

Litvaitis JA (2003) Shrublands and early-successional forests: critical habitats dependent on disturbance in the northeastern United States. For Ecol Manage 185:1-4

McGowan KJ, Woolfenden GE (1989) A sentinel system in the Florida scrub jay. Anim Behav 37:1000-1006

Mumme RL (1992) Do helpers increase reproductive success? An experimental analysis in the Florida scrub jay. Behav Ecol Sociobiol 31:319-328

Mumme RL, Bowman R, Pruett MS, Fitzpatrick JW (2015) Natal territory size, group size, and body mass affect lifetime fitness in the cooperatively breeding Florida scrubjay. Auk 132:634-646

Myers RL (1990) Scrub and high pine. In: Myers RL, Ewel JJ (eds) Ecosystems of Florida. University of Central Florida Press, Washington, DC, p 150-193

Perry RW, Thill RE (2013) Long-term responses of disturbance-associated birds after different timber harvests. For Ecol Manage 307:274-283

Core Team (2020) R: a language and environment for statistical computing. R Foundation for Statistical Computing, Vienna. www.R-project.org/

Schlossberg S, King DI (2008) Are shrubland birds edge specialists? Ecol Appl 18:1325-1330

Shake CS, Moorman CE, Riddle JD, Burchell MR II (2012) Influence of patch size and shape on occupancy by shrubland birds. Condor 114:268-278

Soil Conservation Service (1968) Soil survey of Ocala

Editorial responsibility: Michael Reed,

Medford, Massachusetts, USA

Reviewed by: 2 anonymous referees
National Forest area, Florida. US Department of Agriculture and University of Florida, Gainesville, FL

Stith BM (1999) Metapopulation dynamics and landscape ecology of the Florida scrub-jay (Aphelocoma coerulescens). PhD dissertation. University of Florida, Gainesville, FL

Stith BM, Fitzpatrick JW, Woolfenden GE, Pranty B (1996) Classification and conservation of metapopulations: a case study of the Florida scrub jay. In: McCullough DR (ed) Metapopulations and wildlife conservation. Island Press, Washington, DC, p 187-216

Thompson FR III, DeGraaf RM (2001) Conservation approaches for woody, early successional communities in the eastern United States. Wildl Soc Bull 29:483-494

Thompson SK (2012) Sampling, 3rd edn. Wiley, New York, NY

USFS (US Forest Service) (1999) National forests in Florida: Land and Resource Management Plan. USFS, Tallahassee, FL. www.fs.usda.gov/detail/florida/landmanagement/ planning/?cid=stelprdb5269793. Appendix E: www.fs. usda.gov/Internet/FSE_DOCUMENTS/fsbdev3_007278. pdf (accessed 6 June 2019)

USFS (2009) Land and Resource Management Plan Amendment 8. USFS, Tallahassee, FL. www.fs.usda.gov/Internet/ FSE_DOCUMENTS/fsbdev3_007272.pdf (accessed 6 June 2019)

USFWS (US Fish and Wildlife Service) (1987) Endangered and threatened wildlife and plants; threatened status for the Florida scrub-jay. 50 CFR Part 17. Federal Register Vol 52, No. 106, Proposed Rules, May 21, 1986

USFWS (2007) Florida scrub-jay (Aphelocoma coerulescens) 5-year review: summary and evaluation. USFWS, Jacksonville, FL. www.fws.gov/northflorida/scrub-jays/ 2007-Review/2007-Florida-scrub-jay_5-Year_review.pdf (accessed 6 June 2019)

*Watson SJ, Taylor RS, Nimmo DG, Kelly LT, Haslem A, Clarke MF, Bennett AF (2012) Effects of time since fire on birds: how informative are generalized fire response curves for conservation management? Ecol Appl 22: 685-696

WWeekley CW, Menges ES, Berry-Greenlee D, Rickey MA, Clarke GL, Smith SA (2011) Burning more effective than mowing in restoring Florida scrub. Ecol Restor 29:357-373

Williges K, Kubilis P, Ellenberger J, Hansen P, McMillian M (2006) Effects of management regimes on restoring longunburned scrub to an early successional structure favored by obligate scrub species. Final Report, Florida Fish and Wildlife Conservation Commission, Gainesville, FL

Woolfenden GE, Fitzpatrick JW (1984) The Florida scrub jay: demography of a cooperative-breeding bird. Princeton University Press, Princeton, NJ

Woolfenden GE, Fitzpatrick JW (1996) Florida scrub-jay (Aphelocoma coerulescens). In: Poole A, Gill F (eds) The birds of North America, No. 228. The American Ornithologists' Union, Washington, DC, p 1-28

Submitted: August 3, 2020

Accepted: March 24, 2021

Proofs received from author(s): May 23, 2021 